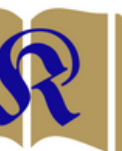

KURIOS

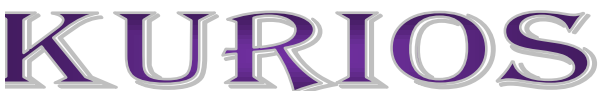

(Jurnal Teologi dan Pendidikan Agama Kristen)

ISSN 2615-739X (print), 2614-3135 (online)

Vol. 4, No. 1, April 2018 (56-73)

\title{
Presuposisi Kitab Kisah Para Rasul dalam Rancang Bangun Teologi Pentakosta
}

\author{
Harls Evan R. Siahaan \\ Sekolah Tinggi Teologi Pelita Bangsa Jakarta \\ evandavidsiahaan@gmail.com
}

\begin{abstract}
The construction of theology of Pentecost is very important in modern Pentecostalism movement, in order, at least, could reflecting this movement as a continuity of the prior one and giving responsible of biblical foundation. This article purposed to show a logical foundation of using The Book of The Acts as biblical based of Pentecostalism movement. The author used a method of analyzing of the historical and pholosophical essence of The Acts itself. And the conclusion is, that The Book of Acts has a theological presupposition, so that could be mostly used as a base of the theology of Pentecost.
\end{abstract}

\footnotetext{
Abstrak

Rancang bangun teologi Pentakosta merupakan hal yang sangat penting dalam gerakan Pentakostalisme modern, agar, setidaknya, dapat merefleksikan kegerakan ini sebagai sebuah kontinuitas dari yang telah ada jauh sebelumnya dan memiliki landasan biblikal yang dapat dipertanggungjawabkan. Artikel ini bertujuan untuk menunjukkan landasan yang logis penggunaan Kisah Para Rasul sebagai dasar kegerakan Pentakostalisme. Penulis menggunakan metode analisis historis-filosofis tentang esensi kitab Kisah Para Rasul itu sendiri. Kesimpulan yang didapatkan adalah, bahwa kitab Kisah Para Rasul memiliki presuposisi teologis, sehingga sangat fondasional jika menggunakannya sebagai dasar teologi Pentakosta.
}

Article History

Submit:

20 February 2018

Accept:

31 March 2018

Publish:

11 April 2018

Keywords:

Pentecostalism; presupposition;

The Acts; theology

of Pentecost

\section{Kata kunci:}

Kisah Para Rasul;

Pentakostalisme;

presuposisi; teologi

Pentakosta 


\section{Pendahuluan}

Rancang bangun teologi Pentakosta yang didasarkan pada kajian Kisah Para Rasul harus memiliki landasan yang kuat dan logis sebagai dasar teologis gerakan ini. Ada semacam tendensi yang digunakan oleh kebanyakan pembicara Pentakosta dalam membangun teologi Pentakosta, di mana lebih sering menggunakan dukungan fenomena Pentakosta secara empiris. Sederhananya, teologi Pentakosta cenderung berawal dari pengalaman-pengalaman rohani, yang kemudian dicari dukungan teks-teks Alkitab demi menghasilkan sebuah landasan biblikal. ${ }^{1}$ Kisah Para Rasul merupakan kitab di mana peristiwa Pentakosta klasik sering dianggap sebagai prototipe atau preseden teologis bagi kegerakan serupa di era modern, sementara ada kalangan yang menganggap landasar atas Kisah Rasul kurang kuat karena Kisah Para Rasul adalah sebuah catatan sejarah.

\section{Pentingnya Presuposisi dalam Teologi}

Teologi tidak hanya hadir untuk memenuhi tuntutan rasional atas studi keilmuan seperti yang dialami disiplin ilmu lainnya. Teologi merupakan ranah unik yang hadir dalam dunia ilmu pengetahuan, karena banyak hal yang muncul di dalam teologi bersentuhan dengan nuansa metafisik. Sementara keunikan yang dimunculkan oleh nuansa metafisik hanya dapat dijangkau dan dipahami iman, sehingga teologi harus mampu mengekspresikannya dalam bahasa epistemologi. ${ }^{2}$ Hal yang sangat mungkin, ketika dalam pergumulan filosofis ini teologi menggunakan pertolongan berbagai disiplin ilmu lain, agar dapat memahami fenomena yang muncul di sekitarnya. Namun demikian, teologi harus tetap jelas pada identitas dirinya.

Pergumulan filosofis yang dialami teologi merupakan hal mendasar untuk menjadi identitas dan landasan dalam berteologi. Bisa disebut sebagai upaya pra-teologi, karena dilakukan sebelum para teolog berteologi atau berasumsi tentang teologi. Pergumulan ini adalah pergumulan tentang sebuah presuposisi dalam teologi.

\section{Paradigma dan Landasan Berteologi}

Landasan berteologi yang dimaksud dalam konteks ini adalah sebuah pijakan awal yang bersifat teknis bagi teolog untuk melakukan kajian terhadap isu-isu teologi. Sebagai sebuah ilmu, teologi merupakan pengetahuan metodis, sistematis, dan koheren, yang memiliki

\footnotetext{
${ }^{1}$ Daniel E Albrecht and Evan B Howard, "12 Pentecostal Spirituality Part One : An Overview of Pentecostal Spirituality" (2017): 235-253.

${ }^{2}$ Peter C. Phan, "Whose Experiences? Whose Interpretations? Contribution of Asian Theologies to Theological Epistemology," Irish Theological Quarterly 71, no. 1-2 (February 24, 2006): 5-28, accessed March 16, 2018, http://journals.sagepub.com/doi/10.1177/0021140006072559.
} 
obyek kajian yang berkaitan dengan hal-hal adi-kodrati. Persoalan adi-kodrati pada obyek teologi terletak pada wahyu Allah yang mengatasi segala kemampuan manusiawi, sementara sifat ilmiahnya tampak pada metode yang digunakan teolog dalam mengadakan penyelidikan serta mengungkapkannya. ${ }^{3}$ Parameter ilmiah biasanya berdasarkan pada kesesuaian obyek dan pengetahuan. Dengan kata lain, teologi harus mengekpresikan kebenaran yang obyektif, maka dengan demikian teologi dipandang sebagai pengetahuan yang bersifat ilmiah. ${ }^{4}$

Obyek materi teologi adalah penyataan (wahyu) Allah yang diejawantahkan dalam bentuk Alkitab. Alkitab yang satu, sebagai sumber kebenaran dan kehidupan rohani iman Kristen dipandang sebagai yang hakiki oleh seluruh gereja Tuhan. Namun, dalam praktiknya, sumber yang satu tersebut telah menghasilkan beragam interpretasi yang diekspresikan dalam beragam bentuk dan warna teologi. Gereja telah bermuara pada kemajemukan organisasional dan denominasional oleh hadirnya teologi yang beragam sepanjang sejarah gereja. Keberagaman ini disebabkan oleh obyek forma yang berbeda dari masing-masing teolog. Obyek forma telah mendorong munculnya beragam perspektif atas satu obyek materi dalam teologi, yakni Alkitab.

Obyek forma suatu ilmu, termasuk teologi, telah mendorong pembentukan presuposisi, yang nantinya akan menjadi paradigma dalam teologi. Paradigma dalam berteologi sangatlah penting untuk menjaga kesinambungan dan harmonisasi teologi itu sendiri dalam satu kerangka pikir yang telah ditentukan oleh satu konstelasi. Presuposisi akan mengeksprersikan paradigma dari satu kelompok teologi tertentu, katakanlah dalam hal ini Pentakostalisme. Teologi Pentakosta memiliki paradigma yang akan membawa arah pemahaman Alkitab yang berbeda dengan kelompok lain, sebut saja Injili. Sekalipun berada dalam aras yang sama, bahkan menjadi induk teologinya, Pentakostalisme sedikit “menyimpang” dari warna teologi Injili.

Persoalan paradigma juga mempengaruhi pembiasan metodologi yang pernah digunakan oleh kelompok Liberalisme di abad XVIII dan XIX, tatkala memancangkan bendera hegemoni terhadap teologi. Era pencerahan yang didorong oleh bangkitnya Rasionalisme dan Empirisme telah melahirkan pola dan metodologi baru dalam memahami Alkitab, yakni metode historis kritis. Sejatinya, metode kritik sejarah dalam Alkitab ini tidak lahir dari ranah teologi, namun memaksakan diri untuk dapat menjadi wacana keilmuan yang

\footnotetext{
${ }^{3}$ Nico Syukur Diester, Pengantar Teologi (Yogyakarta: Kanisius, 1991), 33.

${ }^{4}$ Donald E. Hardy, 'Narrating Knowledge: Presupposition and Background in Flannery O'Connor's Fiction," Language and Literature 6, no. 1 (February 13, 1997): 29-41, accessed March 20, 2018, http://journals.sagepub.com/doi/10.1177/096394709700600102.
} 
rasional dan dapat diterima di lingkungan universitas ${ }^{5}$, telah menarik mekanisme sekular merambah jauh memasuki ranah teologi. Akibatnya, metode kritik sejarah lahir sebagai aktualisasi metodologi sejarah sekular dalam teologi. ${ }^{6}$ Teologi harus tetap memberi ruang nisbah yang cukup jelas terhadap disiplin ilmu lainnya agar tidak mereduksi kebenaran yang asasi pada dirinya.

\section{Fungsi Hermeneutika}

Perbedaan warna teologi umumnya beranjak dari perbedaan perspektif pada teks-teks sekunder yang memicu kontroversial. Adalah tugas hermeneutika menangani pergumulan para pembaca Alkitab dalam memperoleh makna atau arti teks yang dihadapinya, baik dalam bentuk primer maupun yang sekunder. Satu teks tertentu bisa menghasilkan pemahaman yang berbeda dan beragam, sehingga tidak jarang yang berujung pada perpecahan, hanya karena memperoleh kekayaan makna teks. Seharusnya persoalan-persoalan polisemi tersebut dapat memperkaya wacana teologi sehingga dapat menyentuh banyak aspek hidup manusia.

Perpecahan gereja yang disebabkan oleh perbedaan interpretasi Alkitab seringkali terjebak oleh konstruksi paradigma individual dan kelompok dalam interaksi teks-teks Alkitab. Hal ini wajar, karena setiap teolog tidak akan pernah benar-benar bersih dari paradigma individualnya dalam memahami Alkitab. Perbedaan makna selalu ada, dan seyogyanya menjadi refleksi dari keunikan tubuh Kristus. Setiap metode dalam proses hermeneutika memiliki keunikan, termasuk pola interpretasi empiris yang digunakan oleh kelompok Pentakosta/Kharismatik. ${ }^{7}$ Interpretasi empiris bukanlah satu-satunya, karena, menurut Mark J. Cartledge, metode teologi Pentakosta dalam proses teologi praksis harus membuka diri juga terhadap budaya. ${ }^{8}$

Persoalan-persoalan tersebut sejatinya adalah domain hermeneutika. Seringkali satu kelompok menganggap apa yang mereka lakukan terhadap interpretasi teks lebih tepat dan benar, dibandingkan dengan kelompok lain. Kesalahan mungkin saja terjadi dalam proses interpretasi, namun paradigma atau presuposisi satu kelompok atas teks Alkitab tentunya berbeda dengan yang lainnya. Paradigma memegang peranan yang penting dalam proses hermeneutika. Presuposisi yang digunakan seseorang memandang Alkitab menentukan arah

\footnotetext{
${ }^{5}$ Halim Wiryadinata, "An Evaluation Of Liberation Theology in The Light Of Its Praxis," KURIOS (Jurnal Teologi dan Pendidikan Agama Kristen) 1, no. 1 (2013): 1-10.

${ }^{6}$ John Goldingay, The Authority of The Old Testament (England: Apollos, n.d.), 116.

${ }^{7}$ Brian Howell, "Practical Belief and the Localization of Christianity: Pentecostal and Denominational Christianity in Global/local Perspective," Religion 33, no. 3 (2003): 233-248.

${ }^{8}$ Mark J. Cartledge, "Pentecostal Theological Method and Intercultural Theology," Transformation: An International Journal of Holistic Mission Studies 25, no. 2-3 (April 2008): 92-102, accessed February 21, 2018, http://journals.sagepub.com/doi/10.1177/026537880802500304.
} 
hermeneutika orang tersebut. ${ }^{9}$ Presuposisi akan menentukan arah hermeneutik, karena di dalam presuposisi itulah terletak kunci memahami teks.

\section{Fungsi Apologetika}

Kelemahan dan kesalahan dalam memahami presuposisi kerap berbuah kontroversi dan serangan-serangan atas konstruksi teologi yang dibangun atas presuposisi tersebut. Pertanyaan-pertanyaan yang sering muncul, sejatinya, bukanlah mempermasalahkan warna teologi, melainkan presuposisi yang menjadikan teologi itu berwarna. Kesalahan yang berkaitan presuposisi lainnya, adalah karena teolog tidak memperhatikan atau membangun sebuah presuposisi terlebih dahulu dalam berteologi. Hal ini sering dialami oleh kebanyakan teolog Pentakosta, ketika melakukan konstruksi teologi melalui kajian Kisah Para Rasul yang cenderung mengabaikan konstruksi presuposisi. Penggunaan Kisah Para Rasul oleh kaum Pentakosta sebagai dasar teologi sering beranjak pada asumsi Alkitab sebagai firman Allah yang berotoritas dan berlaku sepanjang zaman, sehingga mengabaikan presuposisi historis kitab ini, yang mana absurd untuk dijadikan norma teologis.

Keterkaitan antara penutur dan penerima wacana merupakan prinsip presuposisi yang mendasar, begitu pun dalam ranah teologi. Keterkaitan tersebut diekspresikan dalam substansi pesan yang disampaikan oleh para penulis Alkitab. Para penulis Alkitab merupakan penutur yang memiliki presuposisi terhadap pesan dan konteks penerimanya, sehingga bahasa yang diekspresikan pun tidak mengandung kesenjangan teologis bagi penerimanya saat itu. Jika kemudian terjadi pertentangan di zaman sekarang ini, persoalan tersebut pada hakikatnya adalah kesenjangan konteks yang harus dipahami dalam kerangka presuposisional. Tugas teolog sebagai seorang apologet adalah mempresuposisikan Allah dalam teologi yang dibangunnya, bukan sekadar membuktikan kesalahan pihak lawan atau kebenaran sendiri. ${ }^{10}$ Sejatinya, setiap perjumpaan apologetik harus berakhir pada presuposisi tentang Allah.

\section{Rekonstruksi Presuposisi Kitab Kisah Para Rasul}

Presuposisi Kisah Para Rasul merupakan acuan dasar atau kerangka logis untuk memahami kitab tersebut dalam sebuah olah interpretasi teks ataupun upaya teologisasi. Dasar inilah yang akan mengarahkan pola pemahaman dan nuansa dogmatis yang muncul dari pembacaan kitab. Penafsiran dan olah teologisasi tidak akan melampaui batasan presuposisi

${ }^{9}$ R. Kendall Soulen, "The Believer and the Historian," Interpretation: A Journal of Bible and Theology 57, no. 2 (April 8, 2003): 174-186, accessed February 21, 2018, http://journals.sagepub.com/doi/10.1177/002096430005700206.

${ }^{10}$ Daniel J. Saunders, “A Definition of Scientific Apologetics,” Theological Studies 5, no. 2 (May 4, 1944): 159-183, accessed March 18, 2018, http://journals.sagepub.com/doi/10.1177/004056394400500203. 
sebuah kitab, karena hal tersebut akan mengabaikan konteks. Oleh karena itu, rekonstruksi presuposisi Kisah Para Rasul begitu penting dalam upaya teologisasi, terlebih yang dilakukan oleh kaum Pentakostalisme.

\section{Presuposisi Historis}

Hampir tidak ada bantahan jika dikatakan bahwa Kisah Para Rasul merupakan kitab sejarah, karena sepanjang kitab ini menceritakan serangkaian peristiwa yang berkaitan dengan kehadiran gereja Tuhan serta persebarannya di sekitar Timur Tengah saat itu. Tambahan lagi, karakter unitas Lukas - Kisah Para Rasul telah mengindikasikan adanya kontinuitas penelitian dari sang ilmuwan tentang catatan sejarah. Hal ini senada yang diungkapkan oleh Luke Timothy Johnson dan Daniel J. Harrington, bahwa Kisah Para Rasul bukan saja hadir dalam tataran Helenistik, melainkan menjadi catatan sejarah yang layak tentang kelahiran gereja. ${ }^{11}$

Beranjak dari fakta-fakta atau catatan sejarah yang diperlihatkan dalam Kisah Para Rasul, maka ada sebagian teolog mengklasifikasikannya ke dalam kitab sejarah. Pengklasifikasian inilah yang secara tidak langsung telah menciptakan presuposisi kitab tersebut, yakni presuposisi historis. Hal ini cukup beralasan melihat alur yang terdapat dalam kitab Kisah Para Rasul cenderung menyajikan peristiwa-peristiwa dari masa lampau, ketimbang norma-norma dogmatis. Pengalaman-pengalaman para rasul, baik kisah Petrus maupun perjalanan misi Paulus bersama rekan-rekan mereka, memberikan nuansa yang kuat kepada kitab ini sebagai sebuah laporan peristiwa perjalanan pelayanan mereka.

Presuposisi historis memberikan kerangka berpikir atau bingkai logis bagi kitab Kisah Para Rasul, bahwa kitab ini harus dipahami dalam signifikansi dan implikasi-implikasi sejarah. Peristiwa-peristiwa yang terjadi di dalam kitab ini merupakan catatan sejarah, yang ketika gereja memperingatinya atau mengajarkannya, hal tersebut terjadi hanya dalam batasan momental. Pengalaman para rasul dan gereja mula-mula tidak dapat dijadikan dasar pengajaran dan pengalaman bagi gereja masa kini, terlebih menjadikannya norma yang bersifat dogmatis. Hal ini disebabkan landasan historis yang tidak memiliki sifat yang terulang atau diulang. Sejarah atau momentum peristiwa para rasul bisa saja dijadikan patron atau spirit gereja masa kini, sejauh jejak makna yang ditinggalkan bersifat relevan.

\section{Presuposisi Teologis}

Presuposisi teologis Kisah Para Rasul tidak sekadar hadir sebagai opsi atau jalan keluar untuk menarik sebuah benang merah teologis dari masa purba kepada gereja masa kini.

\footnotetext{
${ }^{11}$ Luke Timothy Johnson and Daniel J. Harrington, The Acts of the Apostles (Minnesota: The Liturgical Press, 1992), 3.
} 
Presuposisi teologis harus dibuktikan dan dipastikan ada secara substansial pada Kisah Para Rasul. Presuposisi teologis tidak untuk menghasilkan argumentasi teologis yang dapat melegitimasi nilai-nilai teologis dan memancangkan hegemoni atas pelbagai praktik kepercayaan. Argumentasi teologis cenderung digunakan untuk melegitimasi beragam praktik keyakinan. ${ }^{12}$ Kecenderungan melegitimasi secara teologis tidak merefleksikan presuposisi teologis, terlebih jika legitimasi itu datang dari ranah ilmu yang berbeda.

Kesenjangan teologis mungkin saja dialami oleh pembaca Kisah Para Rasul pada masa kontemporer. Presuposisi teologis Kisah Para Rasul dibutuhkan lebih dari sekadar memenuhi kepentingan legalitas Pentakostalisme. Presuposisi teologis akan memberikan implikasi teologis yang bersifat normatif dalam upaya teologisasi kitab Kisah Para Rasul yang dilakukan para teolog di setiap zamannya. Kisah Para Rasul, dalam bentuknya yang nyaris historis atau naratif, harus direkonstruksi dalam bentuk yang lebih pantas untuk merepresentasikan norma-norma yang teologis maupun dogmatis. Dengan demikian Pentakostalisme memiliki pijakan yang kuat atas "pengulangan" peristiwa yang menjadi ikon atau identitas teologinya, karena tersusun atas instrumen yang normatif.

\section{Metodologi}

Metode yang digunakan dalam penelitian ini adalah dekriptif historis dan analisis filosofis serta teologis kitab Kisah Para Rasul dalam penggunaannya sebagai dasar teologi Pentakosta. Kisah Para Rasul merupakan sebuah kitab yang cenderung dikenal sebagai sebuah kitab dengan sastera sejarah; sehingga jika hal ini dipertahankan, maka segala bentuk teologi yang dibangun atas dasar penggunaan nas Kisah Para Rasul akan menghasilkan stigma mengulang sejarah. Intinya peristiwa sejarah tidak cukup kuat untuk dijadikan landasan teologi, karena bersifat insidentil, tak berulang dan subyektif. Itu sebabnya perlu mengkaji lagi esensi kitab ini dari segi kepenulisan sasteranya dengan mempertimbangkan latar belakang penulis Kisah Para Rasul itu sendiri.

Penulis menggunakan analisis deskriptif historis untuk melihat secara hakiki dan faktual esensi dari penulisan kitab Kisah Para Rasul. Analisis historis adalah untuk mempertimbangkan latar belakang Lukas sebagai penulis kitab dan pendidikan yang dimilikinya. Pendekatan filosofis digunakan untuk memahami konsep penulisan sejarah dalam konteks budaya Roman-Greco atau Helenisme abad pertama. Pendekatan teologis digunakan untuk memaknai tujuan-tujuan Lukas dalam penulisan kitab Kisah Para Rasul.

\footnotetext{
${ }^{12}$ David F . Ford, Ben Quash Soskice, and Janet Martin, Fields Of Faith; Theology and Religious Studies for the Twenty-First Century (UK: Cambridge, 2005), 163.
} 


\section{Pembahasan}

Presuposisi teologis Kisah Para Rasul dapat diidentifikasi dari beberapa fase, yaitu: dengan menentukan genre Kisah Para Rasul dan menganalisis maksud-maksud Lukas dalam teologinya.

\section{Menentukan Genre Kisah Para Rasul}

Teologi Pentakostalisme membutuhkan sebuah rekonstruksi filosofis dan teologis atas genre Kisah Para Rasul, karena ini menjadi faktor penting dalam presuposisi Kisah Para Rasul sebagai dasar teologi Pentakosta atau gerakan Pentakostalisme.

\section{Non-Historis}

Presuposisi historis Kisah Para Rasul melegitimasi sifat kitab Kisah Para Rasul yang adalah sejarah. Kesejarahan kitab ini akan menjadi penghalang dalam melakukan rekonstruksi fondasi Pentakostalisme. Pentakostalisme harus bersikap tegas atas presuposisi kitab ini, yang tidak menganggap sekadar kitab sejarah, melainkan mampu menunjukan faktor-faktor yang mendukung presuposisi teologis. Ini berarti, bahwa Kisah Para Rasul tidak harus dipandang sebagai kitab sejarah, sementara formasi kitab ini sangat jelas dengan nuansa sejarahnya. Atau, cukup puas dengan bentuk narasi, yang tidak terlalu mempersoalkan fakta sejarah? Sikap Pentakostalisme harus semakin jelas untuk merekonstruksi genre kitab ini.

Bentuk sejarah dalam Kisah Para Rasul janganlah dianggap sebagai sebuah penyajian sejarah semata. Atau, dengan kata lain, kitab Kisah Para Rasul tidak harus diimplikasikan sebagai sebuah laporan atau tulisan yang sedang menceritakan tentang sejarah gereja mulamula. ${ }^{13}$ Kuncinya ada pada Lukas sendiri sebagai penulis kitab ini, apakah ia ingin menyampaikan sebuah laporan rangkaian sejarah, atau implikasi-implikasi teologis melalui beragam peristiwa sejarah tersebut. Lukas sungguh-sungguh bukanlah seorang sejarawan sejati jika paramaternya adalah Kisah Para Rasul.

Perhatian Lukas terhadap kehidupan para rasul hanya terfokus pada dua sosok; Petrus dan Paulus, serta hanya sekelumit menyinggung tentang Yakobus (Kis 12:2). Jika dianggap penulisan Kisah Para Rasul sebagai laporan sejarah, maka, seharusnya Lukas tidak mengabaikan kisah hidup para rasul lainnya, karena keberadaan mereka sangat penting bagi kehidupan gereja saat itu. Lukas pun tidak menyebutkan alasan-alasan terjadinya peralihan kepemimpinan gereja di Yerusalem, termasuk pengangkatan ketujuh orang untuk melayani

\footnotetext{
${ }^{13}$ Thomas E. Phillips, "The Genre of Acts: Moving Toward a Consensus?," Currents in Research 4, no. 3 (June 3, 2006): 365-396, accessed March 20, 2018, http://journals.sagepub.com/doi/10.1177/1476993X06064629.
} 
dalam Kisah Para Rasul 6:1-7. Alasan yang tidak kalah kuat adalah, perluasan gereja ke luar wilayah Timur Tengah, bahkan hingga ke Mesir juga tidak disinggung dalam Kisah Para Rasul. Semua ini menunjukkan ketidaktertarikan Lukas pada masalah biografi atau sejarah, seperti yang diungkapkan oleh Gordon D. Fee dan Douglas Stuart, “...he has no interest in the "lives," that is, biographies, of the apostles." ${ }^{14}$

Ada kemungkinan bahwa apa yang Lukas lakukan adalah menarik sebuah benang lurus yang merepresentasikan pola atau formulasi dalam Kisah 1:8 tersebut, sehingga ia tidak terlalu memberi banyak perhatian pada tempat-tempat lain. Ini alasan atau maksud teologis, bahwa Lukas memang tidak mengidentifikasin dirinya sebagai seorang sejarawan yang merefleksikan dirinya melalui karya Kisah Para Rasul. Melalui penyelidikan yang saksama ia memang mengetahui peristiwa terjadi, namun inspirasi yang kuat telah membawanya pada sebuah rekonstruksi teologis atas laporan peristiwa-peristiwa sejarah tersebut. Joel B. Green menyebutnya narasi, karena menurutnya, “...narasi hanyalah salah satu cara untuk mengomunikasikan kepentingan-kepentingan teologis serta historis.” ${ }^{15}$

Dengan merefleksikan narasi Injil, Samuel Byrskog mengungkapkan: "The gospel narratives are not like fictions telling a story in such a way that the narrative setting in place and time can be replaced by another place and another time.... ${ }^{{ }_{16}}$ Narasi Injil, demikian juga Kisah Para Rasul, merupakan cara untuk mengekspresikan secara seimbang antara sejarah faktual (historie) dan sejarah imani (geschichte). Narasi sangat mungkin menggunakan fakta dari peristiwa sejarah, namun implikasi dan orientasi penyampaian tidak bergantung pada otentisitas sejarah yang disajikan.

Kesimpulan untuk mengatakan Kisah Para Rasul bukanlah kitab sejarah memang tidak bisa sepenuhnya diterima, karena terkesan terlalu dini. Ketidakhadiran beberapa peristiwa yang seharusnya ada dalam sebuah catatan sejarah gereja awal tidak seraya mengeliminir sifat kesejarahan Kisah Para Rasul. Sepertinya, ia terpola dengan formulasi teologis di awal kitab ini, yaitu di dalam Kisah Para Rasul 1:8. Pola "dari Yerusalem" hingga "ke ujung bumi" bisa dipandang sebagai ruang lingkup sajian dari penyelidikan Lukas, yang nantinya, jika laporan mengenai sejarah kelahiran dan persebaran gereja secara geografis tidaklah representatif, maka hal itu dapat dipahami, bahwa sejatinya Lukas tidak sedang melaporkan temuan sejarah.

\footnotetext{
${ }^{14}$ Gordon D. Fee and Douglas Stuart, How to Read the Bible for All Its Worth (Michigan: Grand Rapids, 1982), 92.

${ }^{15}$ Joel B Green, Memahami Injil-Injil Dan Kisah Para Rasul (Jakarta: Persekutan Pembaca Alkitab, 2005), 139.

${ }^{16}$ Samuel Byrskog, Story as History: The Gospel Tradition in the Contexct of Ancient Oral History (Tubingen: Mohr Siebeck, 2000), 2.
} 


\section{Historiografi Yunani}

Istilah "historiografi" secara sederhana berarti tulisan sejarah. Namun esensi historiografi tidaklah sesederhana dalam memahami sejarah pada umumnya, karena standar di antaranya pun berbeda. Tema tentang historiografi Yunani telah dibahas secara khusus oleh penulis sebagai salah satu cara untuk memahami esensi teologi Kisah Para Rasul dalam bentuk artikel pada Jurnal Antusias. ${ }^{17}$ Hal ini tidak akan dibahas lagi secara detail di sini, melainkan sebagai referensi untuk mengerti secara jelas pembahasan historiografi Yunani. Pola historiografi Yunani merupakan pengajaran yang menggunakan materi peristiwa atau hikayat, dengan tujuan untuk memberikan preseden tentang peristiwa tersebut sebagai prototipe dari peristiwa yang mungkin muncul berikutnya.

Dalam kesimpulan penelitian Jurnal Antusias Vol 4, No. 7, penulis menandaskan bahwa hakikat historiografi merupakan kunci untuk memahami tujuan Lukas dalam menampilkan peristiwa Pentakosta klasik di loteng Yerusalem. Lukas tidak sedang membuat laporan peristiwa, melainkan menggunakan pola yang dapat dipahami para pembacanya saat itu, bahwa mereka sedang diajarkan tentang pengalaman rohani yang dibutuhkan dalam kekristenan. Pokok historiografi merupakan indikasi bahwa Kisah Rasul bukan menyajikan sejarah dalam teologi sang penulis, yakni Lukas.

\section{Narasi Historis-Teologis}

Beberapa hal yang telah ditunjukkan di atas, sebagai bukti inkonsistensi Lukas pada tataran historis kitab Kisah Para Rasul, telah mendorong pada pemahaman yang lebih dinamis atas kitab ini. Kisah Para Rasul tidak lagi dianggap murni sejarah dengan presuposisi historisnya, melainkan pola unik yang direfleksikan dari kajian sejarah Yunani kuno; historiografi Helenis. Keberadaan fakta sejarah tidak dipungkiri, namun penyajian yang kurang sistematis tanpa mencakup keseluruhan peristiwa sejarah yang cukup penting saat itu, memungkinkan pola narasi digunakan oleh Lukas untuk menyampaikan norma teologis melalui fakta sejarah. Kisah Para Rasul bersifat narasi, namun berdasarkan pada peristiwaperistiwa sejarah, untuk mengajarkan norma teologis kepada gereja secara berkesinambungan.

Joel B. Green menekankan, bahwa baik surat maupun narasi, “...keduanya sebenarnya hanyalah dua alternatif untuk mengkomunikasikan sebuah pesan.” ${ }^{18}$ Kisah Para Rasul tidak tergantung pada bentuk apa yang sedang digunakan atau dipilih oleh Lukas untuk

\footnotetext{
${ }^{17}$ Evan Siahaan, "MEMAHAMI PENTAKOSTALISME MELALUI BINGKAI HISTORIOGRAFI LUKAS DALAM KISAH PARA RASUL," Jurnal Antusias 4, no. 7 (June 12, 2015): 60-81, accessed October 29, 2017, http://www.sttintheos.ac.id/e-journal/index.php/antusias/article/view/6/5.

${ }^{18}$ Green, Memahami Injil-Injil Dan Kisah Para Rasul, 136.
} 
menyampaikan pesan yang diinspirasikan oleh Roh Kudus kepadanya. Pesan yang ingin disampaikan Lukas, itu yang jauh lebih penting dari sekadar sebuah alur yang harus dipertimbangkan secara sistematis. Peristiwa-peristiwa memiliki implikasi teologis, namun secara simultan terjadi dalam lintasan sejarah, atau mengandung fakta sejarah. Namun, peristiwa sejarah yang dipilih, sejatinya, ada pada pemilihan Roh Allah sebagai inspirator karya Lukas.

Catatan non-historis Kisah Para Rasul dipertegas Philip, bahwa Lukas bukan menulis sekadar sejarah gereja mula-mula, melainkan sejarah politis, sejarah deutronomis dan sejarah apologetis. ${ }^{19}$ Ini tidak berarti bahwa narasi yang dikisahkan Lukas bersifat tidak sejarah atau tidak sesuai dengan kejadian sesungguhnya, karena Lukas menggunakan peristiwa sejarah dalam menyampaikan ajaran teologisnya. Narasi adalah metode atau pola yang digunakan oleh Lukas untuk menyampaikan pesan, dengan mengacu pada sejarah faktual. Narasi juga merupakan ekspresi untuk merangkai peristiwa-peristiwa sejarah dengan menekankan pada substansi teologisasi peristiwa-peristiwa tersebut. Esensi pesan teologis yang disampaikan lewat peristiwa-peristiwa tersebut mengikat narasi pada atribusi teologis sekaligus historis, sehingga genre ideal untuk Kisah Para Rasul bisa dikatakan sebagai narasi historis-teologis.

\section{Menentukan Bingkai Teologis Kisah Para Rasul}

Persoalan berikut, yang tidak kalah prinsip dibandingkan genre kitab adalah, bingkai teologis kitab Kisah Para Rasul. Di bagian awal telah dihadirkan beberapa pandangan atas bingkai teologis kitab Kisah Para Rasul; soteriologi-kristologis, misiologis, eklesiologis, dan pneumatologis. Masing-masing bingkai teologis tersebut memiliki argumentasi dalam mempertahankan konsepnya. Namun, pada bagian ini, bingkai teologis Kisah Para Rasul akan menjadi presuposisi kitab yang akan sangat berpengaruh dalam upaya teologisasi dan interpretasi teks maupun peristiwa di dalamnya.

Kisah Para Rasul tidak boleh dipenjarakan dalam satu bingkai teologi yang bertendensi denominasional, karena upaya itu terjebak pada bingkai dogmatis. Kisah Para Rasul bisa saja berimplikasi pada persoalan-persoalan pneumatologis, karena memberikan nuansa pergerakan Roh Kudus yang cukup elegan di dalamnya. Begitu juga dengan upaya memandangnya dalam perspektif misiologis, ${ }^{20}$ karena sebagian besar kisah di dalam kitab ini menarasikan kegiatan misi Paulus dan para rekanannya. Jika Kisah Para Rasul harus diterangi

\footnotetext{
${ }^{19}$ Phillips, "The Genre of Acts: Moving Toward a Consensus?"

${ }^{20}$ Heryanto David Lie and Heryanto David Lie, "Penggenapan Progresif Misi Allah Dalam Kisah Para Rasul 1:8,” Jurnal Jaffray 15, no. 1 (March 14, 2017): 63, accessed July 27, 2017, http://ojs.sttjaffray.ac.id/index.php/JJV71/article/view/235.
} 
dengan kerangka berpikir soteriologis-kristologis, hal tersebut pun sangat beralasan, karena merupakan bingkai besar dari keseluruhan kronologi Alkitab; heilsgeschichte. Artinya, masing-masing memiliki kepentingan dan etika denominasional dalam merepresentasikan Kisah Para Rasul di lingkungan gereja.

Lukas bukanlah seorang ekspert dalam teologi sistematika, sehingga ia lantang berbicara pada tataran dogmatis. Ia tidak membawa bendera apa pun, tidak mewakili kepentingan denominasi apa pun. Ia bukan milik satu kelompok, dan tidak membawa warna teologi apa pun. Lukas berbicara pada level ilahi, dalam sebuah rumusan teologi Kerajaan Allah, yang bisa saja merepresentasikan bingkai misiologis, soteriologis, penumatologis, atau eklesiologis. Namun, misiologis tidak berdiri sendiri, tanpa implikasi yang jelas. Misiologi Kisah Para Rasul bergerak dalam dinamika pneumatologis, serta mengarah kepada titik soteriologis. Misiologis juga berimplikasi pada eklesiologis. Penumatologi pun bukan tanpa tujuan, karena berdampak pada kehidupan eklesiologis. Semua dimensi dapat menjadi konstruksi dan bingkai teologis Kisah Para Rasul.

Artinya, memahami Kisah Para Rasul secara presuposisional, dalam bingkai pemikiran teologi, janganlah mengarah kepada tendensi dogmatis. Lukas tidak meletakan sebuah landasan teologi sistematika yang absolut dalam narasi Kisah Para Rasul, tetapi cenderung kepada kajian biblikal yang dinamis. Bingkai pemahaman Kisah Para Rasul adalah biblikal, yang dapat merepresentasikan keseluruhan dimensi sistematika. Jika Pentakostalisme dianggap memandang Kisah Para Rasul dalam sebuah kerangka pneumatologis, sesungguhnya itu sebuah dimensi primer, yang diikuti oleh aspek sekunder lainnya. Pentakostalisme Lukas dalam Kisah Para Rasul merupakan proyeksi misiologis yang didinamisasi oleh nuansa pneumatologis. Kandungan kuat dalam proyeksi misiologis dan pneumatologis Pentakostalisme adalah soteriologi. Demikian juga, eklesiologi tidak dapat diabaikan dalam proyeksi Pnetakostalisme Lukas dalam Kisah Para Rasul.

\section{Refleksi Teologi Lukas dalam Kisah Para Rasul}

Memahami Kisah Para Rasul tidak lepas dari peran penulis kitab ini. Pewahyuan dinamis tidak membuat faktor penulis diabaikan secara holistik. Allah tidak mendikte Lukas untuk menuliskan serangkaian kisah para rasul. Eksistensi Lukas secara holistik menjadi konteks yang patut dipertimbangkan dalam memahami Kisah Para Rasul, termasuk pemikirannya. Apa yang diterima, didapat, lalu dituangkan dalam bentuk teologi, yakni teolog Lukas. Artinya, Kisah Para Rasul merupakan refleksi dari teologi Lukas, sekalipun hadir dalam bentuk narasi sejarah. 


\section{Lukas: Sang Teolog}

Konsep kesejarahan Kisah Para Rasul yang diekspresikan dalam bentuk historiografi Helenis membuktikan bahwa Lukas tidak berkompetensi sebagai sejarawan sejati, melainkan teolog. Leon Morris mengatakan, "Memang benar, Lukas itu penting karena sejarah yang ditulisnya, tetapi benar juga bahwa di balik semua yang dia tulis terkandung tujuan teologis yang serius." ${ }^{21}$ Lebih lanjut, Morris pun mengutip pernyataan J. Christian Beker yang mengatakan: "Lukas adalah seorang teolog ulung."22 Pernyataan ini tentu tidak mewakili semua aspirasi teolog, karena ada juga yang tetap melihat Lukas bukan sebagai seorang teolog, seperti halnya Vincent Taylor. Pertentangan tentang Lukas seakan menjadi persoalan tentatif, yang tidak menemui titik temu. Namun J. D. G. Dunn menegaskan tentang Lukas yang merupakan bagian dari tiga teolog besar, di samping Paulus dan Yohanes. ${ }^{23}$

Beberapa teolog mempertanyakan tentang Lukas; apakah ia seorang yang murni Yunani, atau Semitik; E. E. Ellis menganggapnya ia seorang Kristen Yahudi-Helenis, sementara J. Fitzmyer mengatakan ia adalah seorang Semit. ${ }^{24}$ Namanya disebut oleh Paulus bersama dengan teman-teman Yunani lainnya dalam Kolose 4:14 dan Filemon 24 ketika menemai pelayanan Paulus, termasuk ketika hanya dia seorang diri yang menemani Paulus (2 Timotius 4:11). Mengingat pelayanan Paulus yang terkonsentrasi pada orang-orang nonYahudi (Gentile), maka kehadiran Lukas yang menemani Paulus dalam pelayanan bersama Demas dan yang lain layak diperhitungkan sebagai partisipasi pelayan-pelayan dengan latar belakang Yunani. Dictionary of Jesus and the Gospels menyebutkan, bahwa Lukas, kemungkinan besar seorang yang berasal dari Antiokhiadengan pekerjaan sebagai seorang dokter dan kehidupan yang berselebasi. ${ }^{25}$

Ini penting, selain memiliki kemampuan intelektual yang baik Lukas pun memiliki pengalaman rohani yang kuat bersama Paulus. Mungkin tidak begitu jelas asal-usul keluarganya, seperti Paulus mengenal Timotius hingga ke neneknya. Bahkan tentang latar belakang pendidikan kedokterannya pun tidak ada referensi yang jelas ${ }^{26}$ kecuali Paulus menyebutnya dalam Kolose 4:14. Namun ungkapan Paulus tersebut sangat berlasan, mengingat ada penyakit yang dideritanya (2 Korintus 12:7-9), di mana ia membutuhkan perawatan dan diagnosa khusus dari sang dokter.

\footnotetext{
${ }^{21}$ Leon Morris, Teologi Perjanjian Baru (Malang: Gandum Mas, 1996), 198.

${ }^{22}$ Ibid.

${ }^{23}$ Ibid.

${ }^{24}$ Joel B. Green, Scot McKnight, and I. Howard Marshall, Dictionary of the Jesus and the Gospels (England: IVP, 1992), 496.

${ }^{25}$ Ibid.

${ }^{26}$ Henry M. Morris, “Doctor Luke,” http://www.icr.org/article/480/.
} 
Perekrutan Lukas dalam tim misi Paulus boleh menjadi modal yang cukup besar baginya untuk mengenal dunia pelayanan. Ekspresi surat-surat Paulus menggambarkan betapa kuatnya disiplin dan nilai-nilai pelayanan bagi seorang rasul, dan ini pun yang diterapkan kepada setiap orang yang menjadi bagian timnya, termasuk Lukas. Bisa jadi, Lukas bukanlah siapa-siapa pada saat pertama kali mengenal Paulus, sebuah representasi kaum awam yang mendedikasikan dirinya dalam pelayanan. Namun, dalam perjalanannya, ia banyak bertumbuh dalam pengenalan yang kuat, baik kepada Tuhan dan dalam nilai-nilai pelayanannya.

The New Bible Dictionary menyebutkan Lukas sebagai: “...an educated physician...a humble and disciplined writer...Luke unequivocally claims to be an intimate companion of Paul and an eye-witness of happenings related in those sections." ${ }^{27}$ Kata kunci "saksi mata" dari apa yang dialaminya selama bersama Paulus, adalah bukti keterlibatannya yang mendalam pada nilai-nilai Pentakostalisme. Sekalipun Paulus dan Lukas tidak terlibat langsung pada Pentakostalisme perdana di Yerusalem, namun mereka menjadi bagian yang meneruskan formulasi api Pentakostalisme "sampai ke ujung bumi".

Lukas paham betul apa itu Pentakostalisme, bukan beranjak dari wacana empiris semata. Ia merasakan dan mengalaminya bersama Paulus, namun latar belakang seorang ilmuwan telah mendorongnya untuk membuktikannya secara investigatif. Seorang ilmuwan dengan dasar-dasar pendidikan yang baik, dan memiliki spirit pentakostalisme yang kuat dan mendasar, telah mendorongnya untuk menjadi "alat" Tuhan menunjukkan prinsip kebangunan rohani yang telah terjadi pada saat itu.

Dua modal yang dimiliki Lukas, pengalaman rohani bersama sang rasul yang berdedikasi dan pendidikannya yang tinggi, telah menghasilkan formulasi teologi yang mandiri; Lukas tidak berada di bawah pengaruh dan dikte Paulus. Apa yang dialaminya ditindaklanjuti dalam penelitian yang saksama, karena inilah hakikat seorang ilmuwan, melakukan penelitian (pembuktian) terhadap apa yang dialaminya, sehingga menghasilkan konsep yang lepas dari hegemoni Paulus. Sejatinya, teologi lahir dari sebuah refleksi epistemologis sang penulis terhadap apa yang dipahaminya tentang penyataan Allah, lalu menyampaikannya dengan bahasa yang dimengerti, baik oleh dirinya sendiri maupun pembaca saat itu.

\section{Pentakostalisme: Preseden Teologis}

Kisah Para Rasul memuat peristiwa yang sangat penting dalam kitab ini, yaitu hari raya Pentakosta, di mana momen ini sekaligus menjadi identitas teologi kelompok

\footnotetext{
${ }^{27}$ J. D. Douglas and F.F. Bruce, The New Bible Dictionary (England: IVP, 1980), 755-756.
} 
Pentakostalisme kontemporer. Pertanyaan yang membuat maksud Lukas ini menjadi sangat penting, berkaitan dengan persoalan hermeneutik, seperti yang ditegaskan oleh Fee dan Stuart, "If it can be demonstrated that Luke's intent in Acts was to lay down a pattern for the church for all times, then that pattern surely becomes normative..." ${ }^{28}$ Teologi Pentakosta dituntut untuk dapat merekonstruksi presuposisi Kisah Para Rasul pada tatanan yang normatif.

Seperti yang diungkapkan pada bingkai teologi Kisah Para Rasul, apa yang Lukas sajikan melalui kitab ini merupakan upaya normatif Pentakostalisme bagi kehidupan gereja di segala zaman. Pentakosta dalam Kisah Para Rasul 2, di satu sisi, merupakan bagian dari peristiwa sejarah, yang secara faktual telah melahirkan gereja. Di sisi lain, dengan bertolak dari pola penulisan historiografi Helenis, penekanan Lukas bukanlah pada penyajian catatan sejarah tersebut. Peristiwa Pentakosta dinarasikan dengan substansi teologi yang kuat. Sifat historiografi Helenis yang tidak sekadar menyajikan sejarah dalam konsepsi historie menjadi refleksi cara Lukas menyampaikan esensi Pentakostalisme pada pembacanya. Ia sedang menyajikan sebuah peristiwa yang sekaligus menjadi preseden bagi gereja berikutnya.

Faktor Roh Kudus sebagai inspirator kitab Kisah Para Rasul bukanlah sebagai upaya rasionalisasi, atau berkilah dari tuntutan argumentasi—baik pada tataran filosofis maupun teologis - kaum Pentakosta. Faktor ini merupakan presuposisi teologi Injili, bahwa Allah adalah master mind dari semua karya teologis para penulis Alkitab. Lukas mulai dengan sebuah inspirasi, menarasikan temuan peristiwa historis, dengan tujuan mengajarkan peristiwa itu sebagai preseden. Terulangnya kembali peristiwa itu di beberapa tempat dalam narasi Kisah Para Rasul telah mengimplikasikan adanya upaya untuk mengajarkan Pentakostalisme kepada jemaat mula-mula dan gereja-gereja di abad pertama.

Pentakostalisme bukanlah semata-mata pneumatologi, karena Lukas tidak mewakili suara dogmatika. Pentakoslisme bisa berimplikasi eklesiologi, bahkan misiologi. ${ }^{29}$ Tetapi Pentakostalisme harus dipahami dalam terang soteriologi. Lukas dengan Injilnya telah memaparkan dasar-dasar kristologi yang kuat dengan implikasi soteriologi. Maka dalam sequel ini Lukas memperlihatkan kontinuitas karya ilahi dengan ekspresi yang lebih komprehensif; pneumatologi-ekelsiologi-misiologi. Jika menelisik pada narasi keseluruhan kitab ini, maka dominasi Roh Kudus menjadi tokoh sentral yang mengerjakan segala sesuatu dalam dua atau tiga dimensi teologi; pneumatologi-eklesiologi-misiologi. Roh Kuduslah yang

\footnotetext{
${ }^{28}$ Douglas Fee, Gordon D. and Stuart, How to Read The Bible for All Its Worth (Michigan: Academic Book, 1982), 89.

${ }^{29}$ Lie and Lie, "Penggenapan Progresif Misi Allah Dalam Kisah Para Rasul 1:8."
} 
menjadi dinamisator (pneumatologi) misi para rasul (misiologi) dalam jemaat mula-mula (eklesiologi), sehingga mereka bertumbuh secara rapid dan solid.

Rekonstruksi kitab telah menunjukkan kepada dua kemungkinan bentuk presuposisi Kisah Para Rasul; historis atau teologis. Presuposisi itu tidak dimulai dari praduga atau asumsi-asumsi yang akan dibuktikan kelak, bahkan keyakinan seseorang atau golongan. Penting untuk digarisbawahi, bahwa presuposisi yang dibangun bukanlah presuposisi golongan atau kelompok teologi, seperti presuposisi kaum Pentakosta atas kitab Kisah Para Rasul, melainkan presuposisi kitab itu sendiri. Presuposisi kitab beranjak dari beberapa faktor yang mengikat kitab Kisah Para Rasul. Faktor-faktor tersebut telah dibahas di atas, sebagai proses yang membangun presuposisi kitab Kisah Para Rasul.

Penentuan genre yang bermuara pada pemahaman historitas Yunani Kuno (Historiografi-Helenis), menjadi refleksi yang kuat untuk tidak memandang atau menilai kitab ini dalam perspektif sejarah modern. Faktor teologi yang tidak menjurus pada satu ekspresi dogmatika, memperlihatkan Lukas yang benar-benar menghadirkan satu-kesatuan teologi yang utuh antara pneumatologi, misiologi, dan eklesiologi. Bahkan, tendensi apologetika yang hadir dalam kitab ini menunjukkan sisi teologi yang kuat ketimbang sebuah catatan atau laporan peristiwa sejarah. Pentakostalisme modern, yang diekspresikan melalui teologi Pentakosta, tidak memberikan warna terhadap Kisah Para Rasul, dengan warna yang semata-mata pneumatologis. Namun sebaliknya, Pentakostalisme modern hadir dari sebuah kontinuitas historis yang tidak berhenti di kitab ini.

Kemungkinan-kemungkinan itu bukan untuk berspekulasi, melainkan untuk mengekspresikan kemungkinan itu sendiri; kemunginan yang dibangun oleh Lukas dalam pola penulisan dan penyampaian gaya Helenisme. Lukas seperti membentangkan seutas benang merah yang tidak terputus dan berhenti pada karya Kisah Para Rasul. Kemungkinan trito-Lukas bukan untuk berspekulasi, namun untuk menunjukkan sebuah pola yang murni teologis, bukan historis. Benang merah itu bisa jadi sebuah benang historis, yang berawal dar Injil Lukas (proto Lukas), namun tidak berhenti di Kisah Para Rasul (deutro Lukas), terus berlanjut sampai pada sebuah masa di mana benang merah tersebut membentuk sebuah alur teologis, yaitu Pentakostalisme. Benang merah itu sesungguhnya historis (historie) dan teologis (geschichte), kronos dan kairos, yang akan terus menghadirkan Pentakostalisme di segala zaman. Artinya, Pentakostalisme beranjak dari sebuah ekspresi dan refleksi teologi 
Lukas, yang dituangkan dalam narasi historis, sehingga muatan teologi itu telah membentuk sebuah presuposisi kitab Kisah Para Rasul yang adalah teologis. ${ }^{30}$

\section{Kesimpulan}

Lukas tidak berniat menyajikan laporan sejarah gereja mula-mula, karena selain hanya menyebut sebagian kecil rasul saja dalam kitab ini, Lukas juga mengabaikan perluasan gereja yang mencakup beberapa wilayah seperti: Ilirkum, Kapadokia, Mesopotamia, hingga Mesir. Yang perlu dipertimbangkan adalah, bahwa Lukas merupakan seorang ilmuwan yang memilki latar belakang budaya Helenis yang kuat, sehingga narasi sejarah yang disajikan merupakan ekspresi historiografi-Helenisme, bukan sejarah pada konsep modern. Lukas hanya menarasikan fakta sejarah dengan tujuan teologis, sesuai dengan fungsi historiografi-Helenis, bukan untuk melaporkan peristiwa, melainkan mengajarkan. Dengan demikian dapat disimpulkan, bahwa presuposisi kitab Kisah Para Rasul adalah presuposisi teologis, sehingga memberi landasan filosofis sekaligus teologis yang sangat kuat serta normatif untuk menjadikan peristiwa Pentakosta sebagai preseden teologis bagi gereja masa kini.

\section{Referensi}

Albrecht, Daniel E, and Evan B Howard. "12 Pentecostal Spirituality Part One: An Overview of Pentecostal Spirituality" (2017): 235-253.

Cartledge, Mark J. "Pentecostal Theological Method and Intercultural Theology."

Transformation: An International Journal of Holistic Mission Studies 25, no. 2-3 (April 2008): 92-102. Accessed February 21, 2018.

http://journals.sagepub.com/doi/10.1177/026537880802500304.

Chan, Simon K H. "EVIDENTIAL GLOSSOLALIA AND THE DOCTRINE OF

SUBSEQUENCE.” AJPS 22 (1999): 195-211. Accessed November 1, 2017.

http://www.apts.edu/aeimages//File/AJPS_PDF/99-2-schan.pdf.

Diester, Nico Syukur. Pengantar Teologi. Yogyakarta: Kanisius, 1991.

Douglas, J. D., and F.F. Bruce. The New Bible Dictionary. England: IVP, 1980.

Fee, Gordon D. and Stuart, Douglas. How to Read The Bible for All Its Worth. Michigan: Academic Book, 1982.

Ford, David F ., Ben Quash Soskice, and Janet Martin. Fields Of Faith; Theology and Religious Studies for the Twenty-First Century. UK: Cambridge, 2005.

Goldingay, John. The Authority of The Old Testament. England: Apollos, n.d.

Green, Joel B. Memahami Injil-Injil Dan Kisah Para Rasul. Jakarta: Persekutan Pembaca Alkitab, 2005.

Green, Joel B., Scot McKnight, and I. Howard Marshall. Dictionary of the Jesus and the Gospels. England: IVP, 1992.

Hardy, Donald E. "Narrating Knowledge: Presupposition and Background in Flannery O'Connor's Fiction.” Language and Literature 6, no. 1 (February 13, 1997): 29-41. Accessed April 6, 2018. http://journals.sagepub.com/doi/10.1177/096394709700600102.

\footnotetext{
${ }^{30}$ Simon K H Chan, "EVIDENTIAL GLOSSOLALIA AND THE DOCTRINE OF SUBSEQUENCE," AJPS 22 (1999): 195-211, accessed November 1, 2017, http://www.apts.edu/aeimages//File/AJPS_PDF/99-2schan.pdf.
} 
Harrington, Luke Timothy Johnson and Daniel J. The Acts of the Apostles. Minnesota: The Liturgical Press, 1992.

Howell, Brian. "Practical Belief and the Localization of Christianity: Pentecostal and Denominational Christianity in Global/local Perspective." Religion 33, no. 3 (2003): 233-248.

Lie, Heryanto David, and Heryanto David Lie. "Penggenapan Progresif Misi Allah Dalam Kisah Para Rasul 1:8.” Jurnal Jaffray 15, no. 1 (March 14, 2017): 63. Accessed July 27, 2017. http://ojs.sttjaffray.ac.id/index.php/JJV71/article/view/235.

Morris, Henry M. "Doctor Luke." http://www.icr.org/article/480/.

Morris, Leon. Teologi Perjanjian Baru. Malang: Gandum Mas, 1996.

Phan, Peter C. "Whose Experiences? Whose Interpretations? Contribution of Asian Theologies to Theological Epistemology." Irish Theological Quarterly 71, no. 1-2 (February 24, 2006): 5-28. Accessed April 6, 2018. http://journals.sagepub.com/doi/10.1177/0021140006072559.

Phillips, Thomas E. "The Genre of Acts: Moving Toward a Consensus?" Currents in Research 4, no. 3 (June 3, 2006): 365-396. Accessed April 6, 2018. http://journals.sagepub.com/doi/10.1177/1476993X06064629.

Samuel Byrskog. Story as History: The Gospel Tradition in the Contexct of Ancient Oral History. Tubingen: Mohr Siebeck, 2000.

Saunders, Daniel J. "A Definition of Scientific Apologetics." Theological Studies 5, no. 2 (May 4, 1944): 159-183. Accessed April 6, 2018. http://journals.sagepub.com/doi/10.1177/004056394400500203.

Siahaan, Evan. "MEMAHAMI PENTAKOSTALISME MELALUI BINGKAI HISTORIOGRAFI LUKAS DALAM KISAH PARA RASUL." Jurnal Antusias 4, no. 7 (June 12, 2015): 60-81. Accessed October 29, 2017. http://www.sttintheos.ac.id/ejournal/index.php/antusias/article/view/6/5.

Soulen, R. Kendall. "The Believer and the Historian." Interpretation: A Journal of Bible and Theology 57, no. 2 (April 8, 2003): 174-186. Accessed February 21, 2018. http://journals.sagepub.com/doi/10.1177/002096430005700206.

Wiryadinata, Halim. "An Evaluation Of Liberation Theology in The Light Of Its Praxis." KURIOS (Jurnal Teologi dan Pendidikan Agama Kristen) 1, no. 1 (2013): 1-10. 